\title{
Migration flows between levels of the Brazilian urban hierarchy in the period 1980-2010
}

\author{
Rodrigo Coelho de Carvalho* \\ Elin Charles-Edwards ${ }^{* *}$
}

In the 1980s, an inflexion was observed in the spatial redistribution of the Brazilian population, attributed to the relative economic decentralization initiated in the 1970 s, especially regarding industrial activities. These changes in the national space economy led to dramatic changes in the volumes and directions of migration flows. This paper researches the impact of the changing patterns of migration across the Brazilian urban hierarchy over the last three decades to determine if a process of deconcentration, as pointed out by some authors, is, in fact, underway. The flows between different levels of the urban hierarchy were calculated based on census data and represented visually in a series of graphs. If a process of deconcentration is occurring, an increase of flows from urban centres positioned in the higher hierarchical levels to lower order centres is expected. This study indicates a process of population concentration in larger cities, but not in the highest level of the urban hierarchy - which suggests an inflexion of historical metropolization tendencies in Brazil. The growing importance of "Regional Capitals", the second highest level, suggests a process of restructuration and relative decompression of the urban system, although the pace of these changes is slowing down.

Keywords: Spatial (re)distribution of the population. Deconcentration. Internal migrations.

\footnotetext{
* Centro de Desenvolvimento e Planejamento Regional (Cedeplar), Universidade Federal de Minas Gerais (UFMG), Belo Horizonte-MG, Brazil (rccgeo@gmail.com; https://orcid.org/0000-0002-9751-4619).

${ }^{\star *}$ School of Earth and Environmental Sciences, Faculty of Science, The University of Queensland, Queensland, Australia (e.charles-edwards@uq.edu.au; https://orcid.org/0000-0003-2580-207X).
} 


\section{Introduction}

Migration is singular among demographic variables in its ability to redistribute national populations. The direction and impact of redistribution have been shown to vary across countries and over time (REES et al., 2016), with migration typically associated with increased population concentration in early stages of development. Countries at later stages of development, such as the United States (BERRY, 1976), United Kingdom (HALL, 1983) and other Western European countries (FIELDINGS, 1982), have experienced a process of deconcentration or counterurbanisation from the 1970s onwards. In Brazil, as well as in other Latin American countries, internal migration was the main driver of population concentration and metropolitan growth from the end of the nineteenth century to the second half of the 20th Century. By the 1970s, most Brazilians were living in urban areas, and urban-urban migration overtook rural-urban migration as the dominant migration stream (MATOS; BAENINGER, 2004; BRAGA; FAZITO, 2010). Nevertheless, this national trend masks significant heterogeneity across space and over time.

In Brazil, concentration and deconcentration have been shown to co-occur across different regions and at different geographical scales (CARVALHO, 2017), that is, a process of population deconcentration can happen in one geographical scale at the same time that a process of concentration occurs in another. For example, a decline in the relative share of the population in the metropolitan core relative to surrounding municipalities, initially observed in São Paulo, is being replicated in metropolises all over the country, suggesting deconcentration. At the same time, in Northeast Brazil, the tendency has been an increase in the share of the population in the state capitals relative to the states population, i.e. concentration. In this paper, "deconcentration" is approached as a process led by migratory movements downward the urban hierarchy, considering that "internal migrations is now the primary process shaping national patterns of human settlement" (RODRÍGUEZ; ROWE, 2018). The units of analysis are the five urban hierarchical levels proposed by the research "Areas of influence of Cities 2007" or simply “REGIC 2007" (IBGE, 2008). These categories are considered at national scale, encompassing the totality of the Brazilian urban system, without delving deeper in regional contexts and particularities (the exceptions being the states of Rio de Janeiro and São Paulo, given their importance in the processes of population redistribution in Brazil).

This paper seeks to measure the level of population concentration and deconcentration across the Brazilian urban hierarchy systematically using migration data from the 1991 , 2000 and 2010 Censuses. This period was selected because many authors pointed out a process of "population deconcentration" in Brazil from the 1980s onwards, supposedly a delayed reflex of the relative economic decentralization initiated in the previous decade, especially of industrial activities (MARTINE; CAMARGO, 1984; DINIZ, 1993; MATOS; BAENINGER, 2004). To reflect differences in the role of cities within the national settlement system, the centrality classification developed by the Brazilian National Institute of 
Geography and Statistics on the aforementioned research REGIC 2007 (IBGE, 2008) is used. This classification is adopted to capture the complexity of relations in the urban network (e.g. complementarity and interdependence, dominance or subordination), which can be independent of total population size. This allows urban centres located in less densely occupied areas to assume the same level in the urban hierarchy as other cities, despite having smaller populations (IBGE, 2008, p. 11). The paper begins in section 2 , with a discussion on the current understanding of the spatial redistribution of population in Brazil since the 1980s. Then, in section 3, the data and methods used on this study are described. Section 4 shows the results, which are discussed in section 5 .

\section{Contextualization: the spatial redistribution of the Brazilian population from the 1980s onwards}

The 1980s was the decade with the worst economic performance in modern Brazilian history, as well as a period of inflexion of tendencies in population (re)distribution. The emergence of new agglomeration economies outside the Rio de Janeiro-São Paulo axis led to a redirection of migration flows to other regions and increased the retention of the population in areas historically characterized by migration losses (RIGOTTI, 2006). During this period, increased urbanization was observed in the states of Minas Gerais, Rio Grande do Sul, Paraná and in the Centre-West region, as a consequence of industrial deconcentration in the economic core of Brazil (MATOS; BAENINGER, 2004). Following a tendency observed in the main metropolitan regions of Latin America (CHAVEZ et al., 2016), the reduction of the growth rate of metropolises in Brazil was another indicator of population deconcentration during this period. The growth of metropolises in Brazil was already lower than the average rate of urban growth since the 1970s, and this tendency continued in the following decades (MATOS; BAENINGER, 2004). Because of the general decrease in fertility, also observed in other Latin American countries in the same period (CHAVEZ et al., 2016), a reduction in the growth rate of all spatial units was expected. Nevertheless, the decline in metropolitan regions was much higher, marking a significant reversal of the previous trend of concentration in a few localities in the Southeast region (MARTINE, 1994, p. 34).

There is also evidence of deconcentration within metropolitan regions since the $1980 \mathrm{~s}$, when metropolises throughout the country started to lose population to surrounding municipalities. On the other hand, it could be argued that this process configures a process of "concentrated deconcentration" and that no significant reversal of tendencies took place (CHAVEZ et al., 2016). Figure 1 shows the changing population distribution across the main Metropolitan Regions (MRs) of Brazil. From 1991 to 2010, there was a general decrease in the share of the population in metropolitan cores compared with surrounding municipalities (except for the municipality of Manaus, which participation on its correspondent MR remained stable). 
FIGURE 1

Relative participation of the metropolitan core populations and the population of surrounding municipalities - 1991-2010

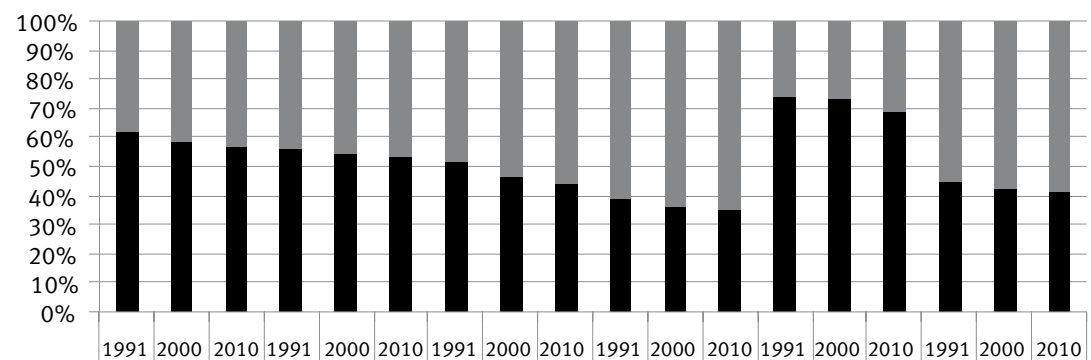

199120002010199120002010199120002010199120002010199120002010199120002010 \begin{tabular}{|l|c|c|c|c|c} 
MR São Paulo & $\begin{array}{c}\text { MR Rio de } \\
\text { Janeiro }\end{array}$ & $\begin{array}{c}\text { MR Belo } \\
\text { Horizonte }\end{array}$ & $\begin{array}{c}\text { MR Porto } \\
\text { Alegre }\end{array}$ & $\begin{array}{c}\text { IRDE DF and } \\
\text { surroundings }\end{array}$ & MR Recife
\end{tabular}

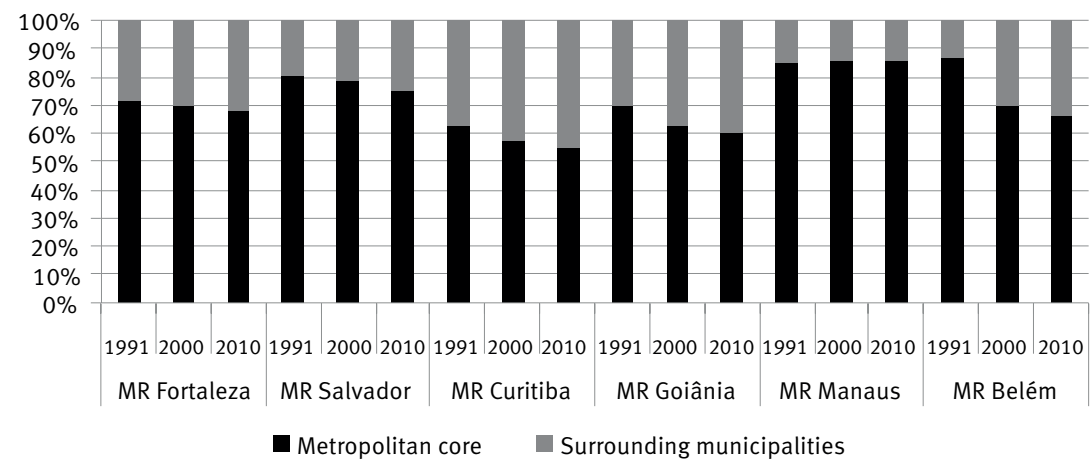

Source: 1991, 2000 and 2010 Demographic Censuses. Prepared by the authors.

At the end of the 1980s, with the end of a cycle of investment and weakening of macroeconomic and regional development policies, industrial deconcentration also lost intensity (CANO, 2011). Migration does not echo patterns of economic development perfectly, and important changes in the processes of population redistribution occurred after this period. Several studies pointed out a process of "deconcentrated urbanization", referring to the growth of intermediate cities. For Matos and Baeninger (2004), geographic dispersion of industrial activities helped to consolidate the Brazilian urban network, increasing the bonds of interdependence and complementarity between different parts of the system. According to these authors, the relative deconcentration of the urban system increased the importance of small and intermediate cities in the country.

The assembled evidence suggests that there is not a consistent direction to population redistribution across Brazil. On the contrary, depending on the geographical scale and region considered, processes of population concentration and deconcentration have coincided. At the national level, the population is becoming more concentrated in urban areas, as captured by the increase in the national urbanisation rate. At the same time, there is long-term stability in the share of the population across the five Brazilian macroregions since the 1980 s, partially due the decline in migration between them. Even within 
macro-regions, Census data show stability in the relative population share of states. For smaller spatial units, the picture becomes more variegated (CARVALHO, 2017). In the Northeast, for example, the macro-region with the lowest urbanization rate in the country, the general tendency in the last decades has been an increase in state capitals share of the states population (except for Recife). This suggests a process of population concentration at the state level, probably intensified by the increase of return migrations from other parts of Brazil. On the other hand, in the Southeast, the proportion of the population residing in the capitals of São Paulo and Rio de Janeiro - the biggest municipalities in the country - has decreased since the 1970s, suggesting a process of deconcentration. To sum up, the assembled evidence strongly suggests that there are processes of population concentration and deconcentration occurring simultaneously in Brazil across different regions and geographical levels. This paper seeks to address this issue, researching the impacts of the changing patterns of migration across the Brazilian urban hierarchy over the last three decades.

\section{Materials and methods}

The data used in this paper were derived from the 1991, 2000 and 2010 Brazilian demographic censuses. Internal migration was measured using a five-year fixed interval measure, that is, the period of analysis starts in the second half of the 1980s (more precisely, from 1986 onwards). According to this measure, a migrant is an individual who resided in a different spatial unit (country, state, municipality or other) from that in which they lived five years before the census reference date. Only migrants aged 5 and over, who are still alive and did not emigrate permanently are captured. Repeat and return moves are also not captured.

Migration questions are present only in the "sample questionnaire" of the census. In the last three censuses, this questionnaire was completed by approximately 10 per cent of the national population, with sample size varying according to the size of municipality populations. The sample is expanded by applying weights to the microdata (IBGE, 2013). This requires some caution in the analysis, especially in very spatially disaggregated areas, as migrants of municipalities with small populations are not accurately captured and thus tend to be underestimated.

To explore the processes of concentration and deconcentration of the Brazilian urban system, the classification of the research "REGIC 2007" (IBGE, 2008) was used to create an origin-destination migration matrix in order to explore the flows between different urban hierarchical levels. If a process of economic and population deconcentration is occurring, an increase of population flows from urban centres positioned in the higher hierarchical levels to lower order population centres is expected.

In order to define the relative position of cities in the Brazilian urban system, REGIC's 2007 classification simultaneously considers cities as a system of central localities 
in command of their hinterlands, as well as a system of articulated cities in a national network (IBGE, 2008, p. 18). The hierarchy of urban centres and their areas of influence were defined using criteria, related to federal management (the centrality of the Executive and Judiciary at the federal level), enterprise management (companies' headquarters) and supply of equipment and services. The goal was to identify cities in the urban network where decisions are made (IBGE, 2008). The outcome was a hierarchical classification of centres as Metropolises, Regional Capitals, Sub-regional Centres, Zonal Centres and Local Centres.

One important feature of REGIC's classification is that the cities' position in the territory was taken into consideration in the classification of the administrative, juridical and economic centrality levels. This means that urban centres located in less densely occupied areas, despite having weaker centrality indicators than centres located in other regions, may assume the same level in the hierarchy (IBGE, 2008, p. 11). A concept like "metropolis", for example, can refer to one type of urban centre in the South or North regions and cities of a very different nature in the Southeast, which reinforces the importance of considering functional spaces instead of merely population sizes.

REGIC's classification was then applied to census data to construct an origin-destination migration matrix of flows between the five urban hierarchical levels. First, each municipality was coded according to its position in the hierarchy. Then, inflows and outflows of each level were summed and organized in a square matrix $(\mathrm{N} \times \mathrm{N})$, with the hierarchical levels of migration origin in the rows and the hierarchical levels of migration destination in the columns. The diagonal of the origin-destination matrix represents migratory exchanges occurred within the same levels and, for this reason, was not considered. In this paper, REGIC's categories are considered at national scale, i.e., encompassing the Brazilian urban system as a whole, regardless of state boundaries or other spatial divisions.

The classification adopted for the period under analysis in this paper (1986 to 2010) was based on the latest edition of REGIC. This means that the same urban hierarchy (referring to the year of 2007) was used in the five-year periods prior to the censuses of 1991, 2000 and 2010. While some variations in the classification may occur across editions of REGIC, the urban hierarchy is relatively stable over time, especially in the upper levels. Despite this, some caution is required for the risk of overestimation of migration flows towards the lowest level of the urban hierarchy ("Local centres"), where new municipalities are typically situated.

Table 1 shows the five categories of urban centres from REGIC 2007, the number of municipalities on each category, and their population and share of the national population. For cities that constitute large urban agglomerations, the spatial unit of analysis was the 
Population Concentration Areas (ACP). ${ }^{1}$ A total of 5,563 municipalities were contemplated in REGIC 2007 and 335 of them were grouped in 40 ACPs. Each one of these 335 municipalities was assigned with the centrality level of the ACPs to which they belong.

TABLE 1

Population and number of municipalities in REGIC 2007 urban hierarchical levels - 1991-2010

\begin{tabular}{|c|c|c|c|c|c|c|c|}
\hline \multirow[t]{2}{*}{ Centrality level } & \multirow[t]{2}{*}{ Frequency } & \multicolumn{3}{|c|}{ Population } & \multicolumn{3}{|c|}{ Population (\%) } \\
\hline & & 1991 & 2000 & 2010 & 1991 & 2000 & 2010 \\
\hline 1) Metropolises & 177 & $47,204,113$ & $56,131,359$ & $62,980,037$ & 32.1 & 33.1 & 33.0 \\
\hline 2) Regional Capitals & 189 & $25,884,789$ & $31,420,281$ & $36,732,148$ & 17.6 & 18.5 & 19.3 \\
\hline 3) Sub-regional Centres & 164 & $12,950,568$ & $14,242,552$ & $16,180,784$ & 8.8 & 8.4 & 8.5 \\
\hline 4) Zonal Centres & 561 & $18,360,307$ & $18,871,679$ & $20,803,138$ & 12.5 & 11.1 & 10.9 \\
\hline 5) Local Centres & 4,472 & $42,425,698$ & $49,133,299$ & $53,883,248$ & 28.9 & 28.9 & 28.3 \\
\hline Total & 5,563 & $146,825,475$ & $169,799,170$ & $190,579,355$ & 100 & 100 & 100 \\
\hline
\end{tabular}

Source: REGIC 2007 and 1991, 2000 and 2010 Censuses. Prepared by the authors.

\section{Results}

Figure 2 shows the migration flows across the urban hierarchy in the five-years prior to the 1991, 2000 and 2010 censuses. The size of the arrows represents the relative share of total internal migration flows, while the direction and colour of the arrow represents the direction of migratory flows. Since relative volumes are depicted in Figure 2, the total area of the arrows is the same in each of the three periods. From Figure 2, it appears that the relative share of migratory movements up the urban hierarchy decreased over the three time periods (Grey arrows) while downward flows increased (Black arrows) suggesting a process of population deconcentration. Changes are bigger between the terminal categories with movements from Metropolises and Regional Capitals to Local Centres showing the biggest increase.

Whereas Figure 2 visualized flows and counterflows simultaneously, Figure 3 shows net migration flows across the urban hierarchy. The arrows in Figure 3 show absolute, rather than relative, values of net migration, and these declined substantially over time. A simple measure called Crude Migration Intensity (CMI) can help understand the magnitude of this apparent fall in the overall level of migrations. It indicates the total number of internal migrants in a given period as a percentage of the population, which dropped from $18.6 \%$ in $1986-1991$ to $15.7 \%$ in $2005-2010$. It is important to highlight that the CMI is scale dependent, that is, the larger the number of spatial units over which migration is measured,

\footnotetext{
1 "ACPs are defined as large urban areas of continuous occupation, characterized by the size and density of the population, the degree of urbanization and internal cohesion of the area, given by the population movements to work or study. ACPs develop around one or more urban centres, in the case of conurbated centres, taking the name of the capital municipality of the municipality with the largest population" (IBGE, 2008, p. 11, own translation). For example, the 177 municipalities included in the first level (metropolises), are part of the ACPs corresponding to São Paulo (the "Great National Metropolis"), Rio de Janeiro and Brasília ("National Metropolises") and Manaus, Belém, Fortaleza, Recife, Salvador, Belo Horizonte, Curitiba, Goiânia and Porto Alegre (simply “Metropolises”).
} 
the higher its apparent intensity (REES et al., 2016). Despite that, even with a growth of more than $18 \%$ in the number of municipalities in the 1990 s due to emancipations, the CMI showed a consistent decrease in the last decades.

The decline in net migration suggests that, irrespective of the direction, the pace of the processes of population redistribution in Brazil is slowing down. In this regard, the Migration Effectiveness Index (MEI) can be helpful to clarify the changes in the overall impact of internal migrations in terms of system-wide distribution. It measures the relationship between net and gross migration and provides an indication of the importance of net migration in redistributing the population, showing how much of internal migrations is "effective" from the point of view of quantitative change (THOMAS, 1941 apud CUNHA, 2014). It consists of the sum of the absolute value of the net migration balance of each spatial unit divided by the sum of total in and out flows across all spatial units, multiplied by 100 . It varies from 0 to 100 , with high values denoting that migration is an efficient mechanism of population redistribution and low values indicating that flows and counter-flows are more closely balanced (BELL et al., 2002). From the first to the last period analysed, MEl suffered a steep decline, going from 29.0 in the period 1986-1991, 25.3 in 1995-2000 and 22.9 in 2005-2010. This means that the decrease of net migrations caused a sharp decrease in the "efficiency" of migration as a mechanism of population redistribution.

Despite being an important statistical measure for comparative and evaluation purposes, the Migration Efficiency Index does not provide an indication of the overall impact of migration on the settlement system, since it does not consider the population of spatial units. To address this issue, Bell et al. (2002) recommend the Aggregate Net Migration Rate (ANMR), which measures the impact of migration on population redistribution, identifying the net shift of population between spatial units per hundred persons resident in the country (REES et al., 2016). It is calculated by dividing the sum of absolute differences between origin and destination flows (aggregate net migration) for the total population and multiplying it by 100 or simply changing the denominator of MEl from the sum of gross migration flows to the population.

There was a steady decline of the ANMR over the last three decades, indicating low and weakening impacts of migration on population distribution: $5.4 \%$ between 1986 and1991, 4.6\% between 1995 and 2000 and 3.6\% in 2005-2010. Nevertheless, a limitation of the ANMR measure is that, since it is a product of the crude migration intensity (CMI) and the migration effectiveness index (MEI), the same value can be a result of high MEl combined with low CMI or the opposite (REES et al., 2016). In other words, migrations can cause a high impact on the settlement system due to a big proportion of migrants in the population, even with relatively balanced flows between the spatial units or, alternatively, due to a small proportion of migrants associated with very unbalanced flows. The fall of both migration intensity and effectiveness in Brazil suggests that the decreasing effect of migrations on the settlement pattern is due to the decreasing proportion of migrants in the population and a greater equilibrium of migration flows and counter flows. 
In all three periods represented in Figure 3, regions in the upper levels of the urban hierarchy mostly gained migrants from regions lower in the hierarchy. The exception are Metropolises, which lost migrants to Regional Capitals in all periods, and Zonal centres, which lost population to Local centres in 1995-2000 and 2005-2010 - which contradicts the aforementioned tendencies of population deconcentration. Nevertheless, it is important to highlight that the biggest migratory gain was not in the highest level of the urban hierarchy, but in the level of Regional Capitals. Furthermore, the biggest migratory gain downwards the urban hierarchy in the three periods considered is the result of the exchanges between Metropolises (1st level) and Regional Capitals (2nd level).

\section{FIGURE 2}

In and out-migration flows through the Brazilian urban hierarchy - 1986-1991 to 2000-2010 1986-1991

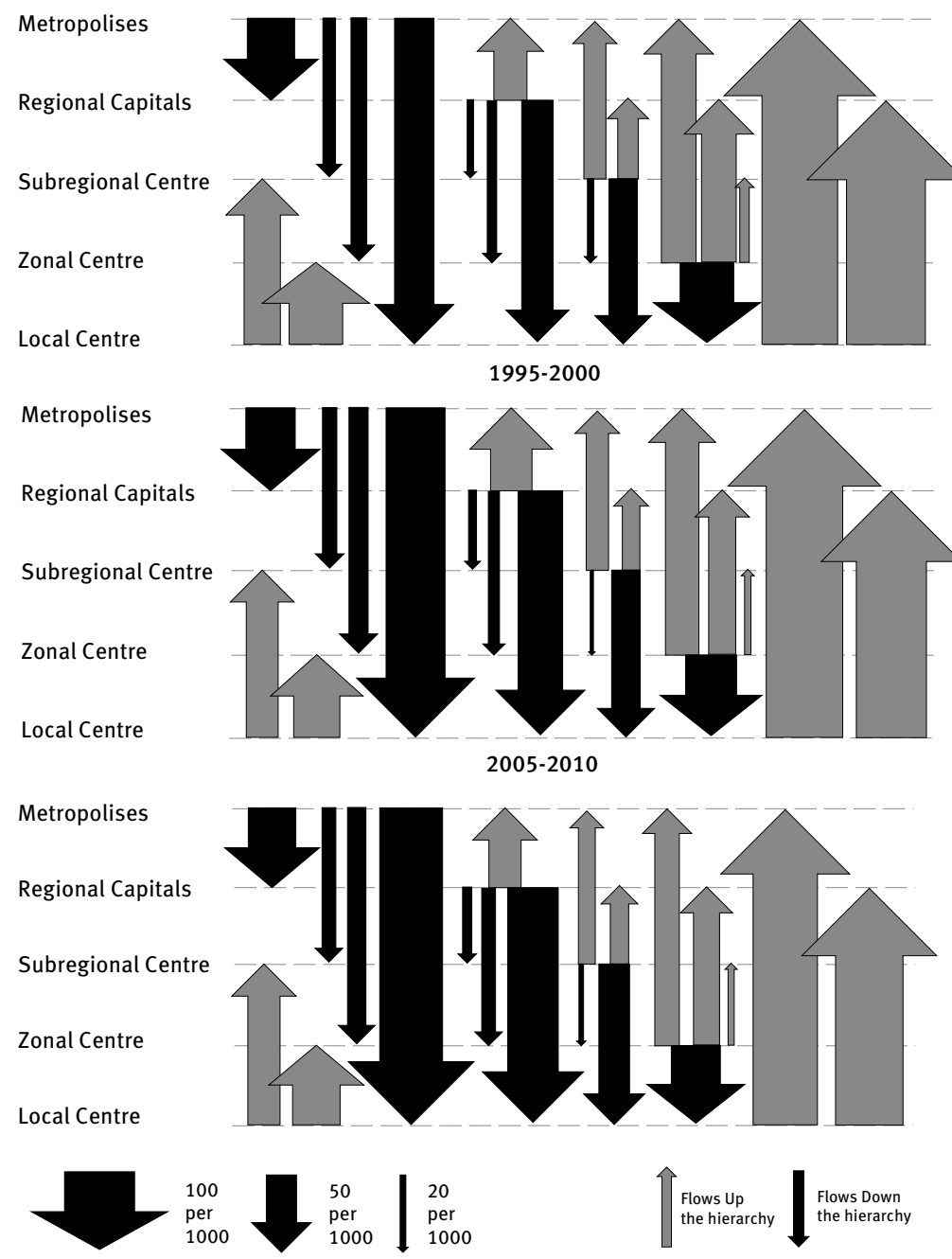

Source: 1991, 2000 and 2010 Demographic Censuses. Prepared by the authors. 
FIGURE 3

Net migration flows through the Brazilian urban hierarchy - 1986-1991 to 2000-2010 1986-1991

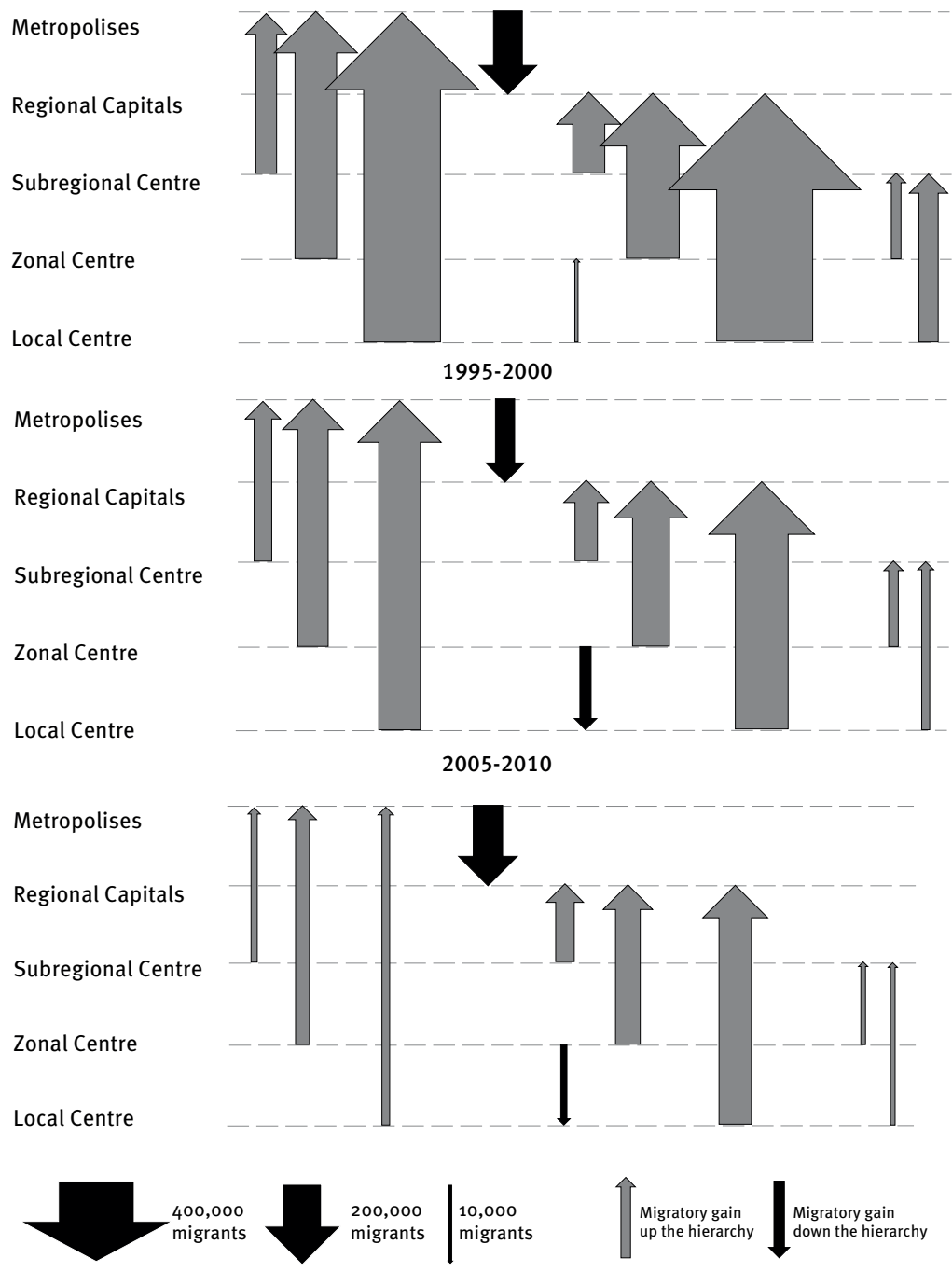

Source: 1991, 2000 and 2010 Demographic Censuses. Prepared by the authors.

Figures 4 and 5 show population exchanges between urban hierarchical levels in the subnational space corresponding to the "São Paulo-Rio de Janeiro axis", which can be considered the core of the national settlement system. These cities are the biggest municipalities in the country and the main centres of what some authors call the "Brazilian Megalopolis" or “Megalopolis of the Brazilian Southeast” (QUEIROGA; BENFATTI, 2007). In addition, the city of São Paulo is the core of the so-called "Macrometropolis of São Paulo" (SILVA et al., 2017). Both cities played an important historical role as vectors of population redistribution, as well as its respective and 
namesake states. The migratory flows within the state of São Paulo, represented in Figure 4, are, by far, the largest between all Brazilian states, corresponding to more than a fifth of all intra-state migrants in the three periods analysed. ${ }^{2}$ Although the migratory flows within the neighbour state of Rio de Janeiro are much smaller, they are also represented in Figure 5 to serve as a basis for comparison. In both, the largest migratory net exchanges are from the highest level downward the urban hierarchy, suggesting a process of "intraregional deconcentration".

The highest level of Figure 4 - corresponding to the "São Paulo ACP" - lost significant amounts of migrants to all other levels in all periods considered, especially between 1995 and 2000. In the following period, these losses were reduced, although the relative configuration of flows remained unchanged. Another feature of the system is the positive migration gain of the second level ("Regional Capitals") in all periods. The third level ("Sub-regional Centres") also showed a positive net migration, albeit to a lesser extent, suggesting the relative deconcentration of the urban network in the state of São Paulo. The general pattern and direction across all levels of the hierarchy was the same across all periods, with two exceptions - the tendency of "Local Centres" to lose migrants to "Zonal Centres" and "Sub-regional Centres" was reversed in the second and third period, respectively, supporting a pattern of deconcentration in this part of the Brazilian urban system.

Migration within the state of Rio de Janeiro shows a more uniform deconcentration trend (Figure 5), with some distinct features when compared to São Paulo. The first level, which corresponds to the ACP of Rio de Janeiro, shows an increasing trend of migration losses from all other levels in the urban hierarchy over the period under study, except for Regional Capitals. In the first two periods, the only migratory gain to Rio de Janeiro was from Regional Capitals, however, this reversed to a net migration loss in the last period, strengthening the tendency toward deconcentration of the urban system of Rio de Janeiro. Between 2005 and 2010, the fourth level of Zonal Centres was the only level to show a migratory loss up the urban hierarchy (to the second and third levels). A feature of Figure 5 are the positive migratory gains of Local Centres (lowest level), which increased over time. Another feature which stands out is the migratory gain of Sub-regional Centres (3rd level), mainly from the Rio de Janeiro ACP and from Regional Capitals, the most important level in the case of the state of São Paulo (since it received the biggest migratory gains).

\footnotetext{
2 More precisely, $21.4 \%$ in $1986-1991$ (1,906,536 migrants), $22.4 \%$ in $1995-2000(2,240,336)$ and $21 \%$ in $2005-2010$ $(1,819,723)$
} 
FIGURE 4

Net migration flows through the urban hierarchy

São Paulo - 1986-1991 to 2000-2010

1986-1991

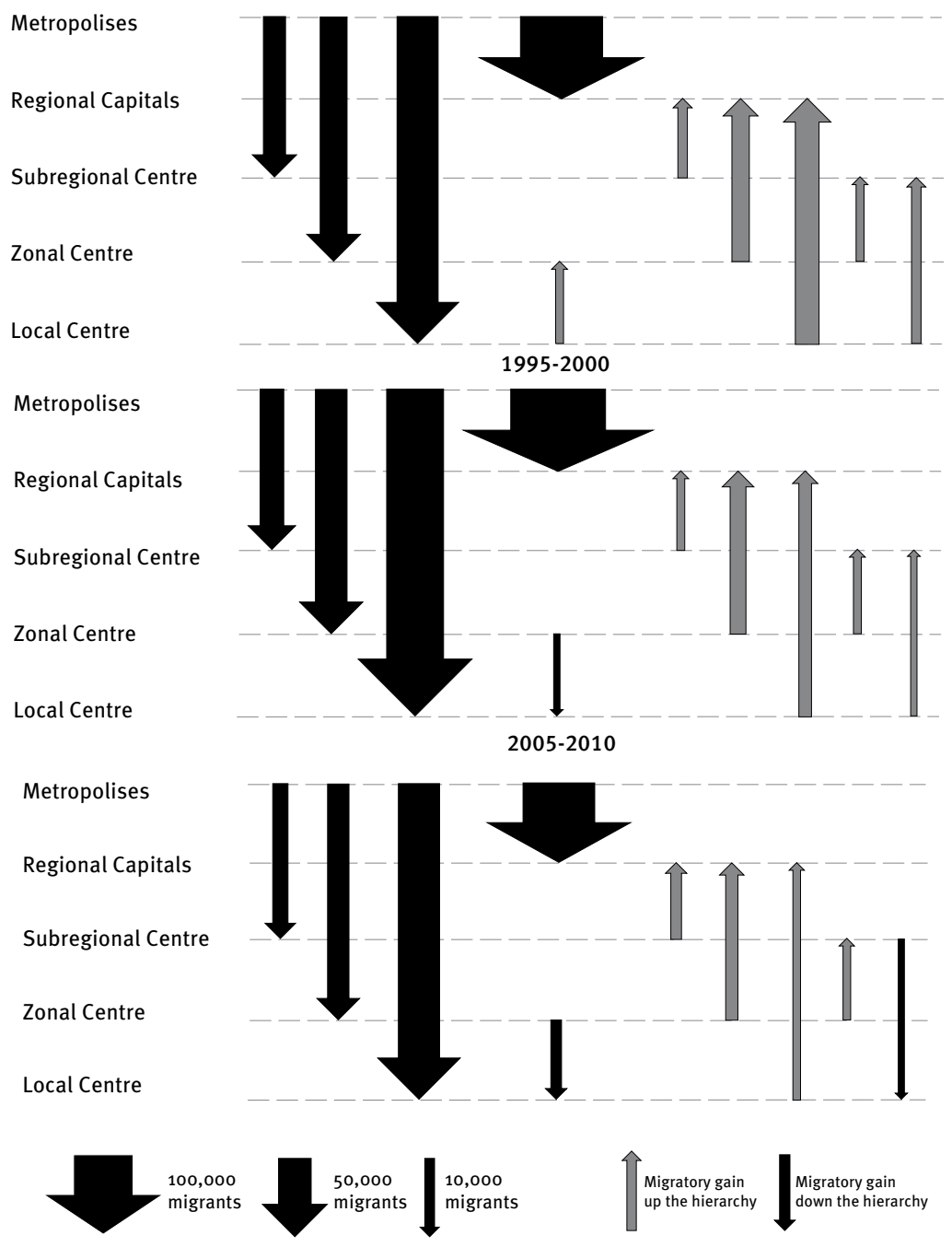

Source: 1991, 2000 and 2010 Demographic Censuses. Prepared by the authors. 
FIGURE 5

Net migration flows through the urban hierarchy

Rio de Janeiro - 1986-1991 to 2000-2010

1986-1991

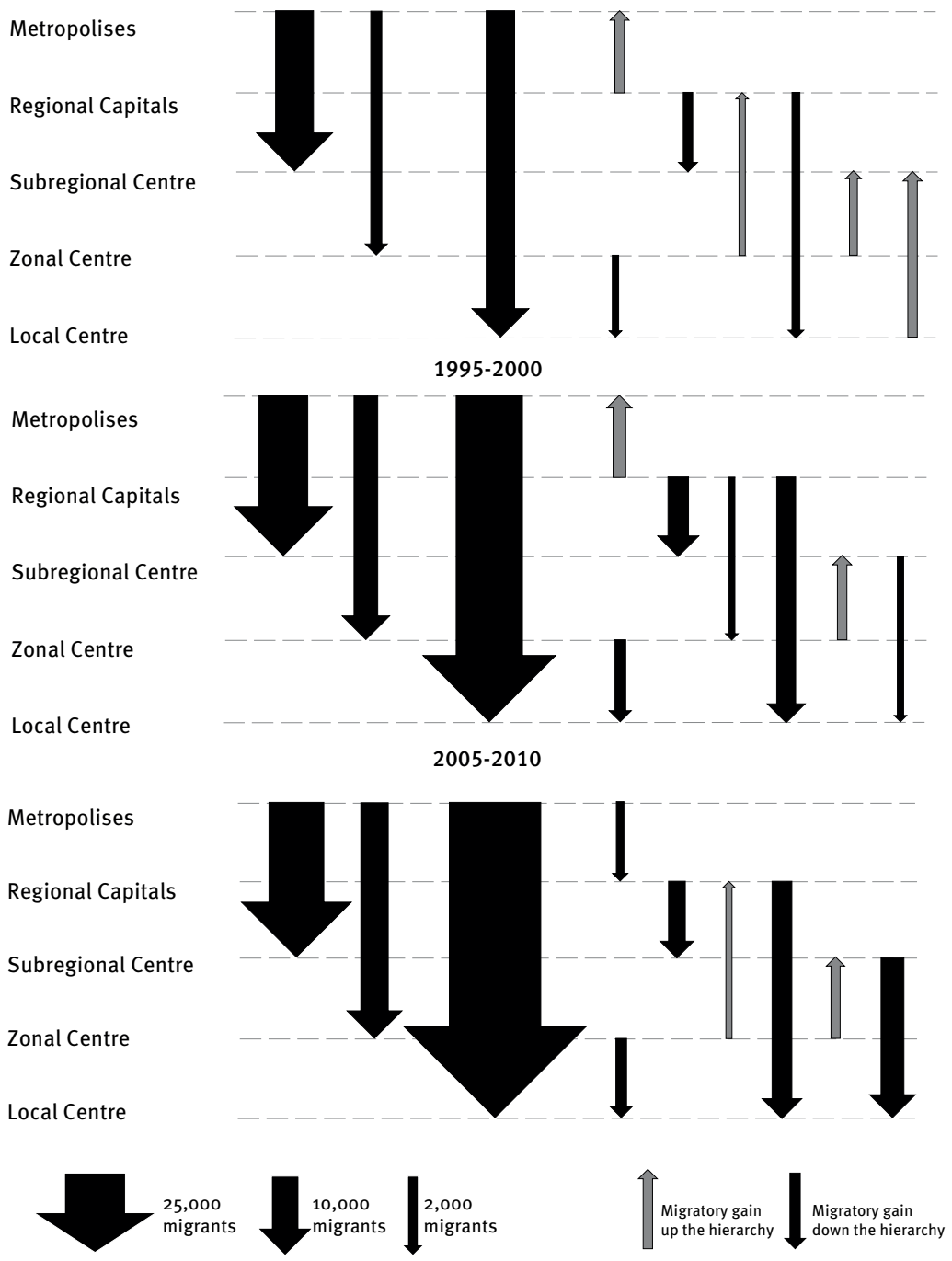

Source: 1991, 2000 and 2010 Demographic Censuses. Prepared by the authors. 


\section{Discussion}

The results of this study show that the biggest migratory gains in the Brazilian urban system since the 1980s did not occur at the highest level but in the Regional Capitals. In REGIC's classification, this category is the most closely related to intermediate cities. From the 1970s onwards, this concept started to become associated with the notion of articulation or connection within the urban system (AMORIM FILHO; SERRA, 2001, p. 19), rather than a definition based simply on population size. They are typically characterized as dynamic and strategic centres with the power to promote the articulation between metropolises and smaller cities or rural areas. ${ }^{3}$

Amorim Filho and Serra (2001), and Correa (2007), demonstrated that the accelerated growth of metropolises since the middle of the last century imposed an additional function on intermediate cities: their capacity to absorb part of the flows from smaller cities or rural areas through the provision of job opportunities, which could help to avoid the strengthening of social problems on large cities. This is in line with the findings of this paper, which indicates that the growth of secondary centres in the last decades is being supported by internal migration across the urban network. The figure representing net migration flows through the Brazilian urban hierarchy (Figure 3) shows that Regional Capitals had a positive net migration in the three periods evaluated, receiving inflows of migrants both from above (Metropolises) and below (Subregional, Zonal and Local Centres).

According to several authors (AMORIM FILHO; SERRA, 2001; MATOS; BAENINGER, 2004; BRITO, 2006; CORREA, 2007), intermediate cities started to grow in importance in the Brazilian urban network since the 1970 s due to the formation of agglomeration diseconomies (especially in the Southeast) and consequent slowdown of the metropolization process in the country. By that time, some metropolitan regions, consolidated as poles of attraction of migrants, began to show signs of loss of attraction power in favour of intermediate urban centres. This trend continued in subsequent decades, as suggested by Figure 3.

The differences observed between internal migrations in São Paulo and Rio de Janeiro show that there is a regional heterogeneity regarding processes of population (re) distribution even within the core region of the national settlement system. Considering the overall patterns of flows in the Brazilian urban system and the patterns shown by the states of São Paulo and Rio de Janeiro, it is possible to infer that a pattern of concentration in the upper levels of the urban hierarchy is predominant in the rest of the country. The prominence and high migratory gains of Regional Capitals is particularly relevant, because if new agglomeration economies are being formed outside the core region, it would indicate an ongoing process of interregional deconcentration. The fact that the most important metropolises are growing at a slower pace in comparison with the rest of the country and

\footnotetext{
${ }^{3}$ This attribute would be one of the reasons why the topic of intermediate cities received so much attention since the 1970s, given that the national urban system was marked by deficiencies and a poor spatial distribution of dynamic intermediate urban centres, an obstacle for an effective interiorization and diffusion of development (AMORIM FILHO; SERRA, 2001).
} 
the tendency of reduction in the proportion of the population in metropolises cores also point in this direction.

By way of conclusion, despite the robustness of REGIC's classification, it must be highlighted that, as spatial statistical data are conditioned by the way and the number of units a given space is divided, ${ }^{4}$ migration estimates are conditioned by the geographical definition of spatial units (CHAVEZ, 2016). As any other classification system, it is susceptible to criticism, especially considering the significant changes in the morphology and functioning of urban systems in many countries around the world in the last decades (JANOSCHKA, 2002; MATTOS, 2010; LENCIONI, 2013; CHAVEZ, 2016; SILVA et al., 2017). In order to make sense of these changes and interpret the new urbanization patterns and processes, a plethora of new concepts was proposed. Terms as "extensive urbanization" (MONTE-MÓR, 1994, 2007), “urban-regional arrangements” (MOURA, 2009), “widespread urban" (MATTOS, 2010) and many others refer, roughly speaking, to the spatial diffusion of different dimensions of urbanization processes, the increasing blurring of the urban-rural dualistic notion and the widespread of more modern and capitalist forms of (re)production of space. Depending on the chosen conceptual framework, some authors could even dispute that migratory movements downwards the urban hierarchy could be considered a process of "deconcentration" and not only a manifestation of the intensification or spatial diffusion of the urban phenomena.

Despite all controversies, the Brazilian National Institute of Geography and Statistics have incorporated many of these contemporary views in REGIC 2007 (IBGE, 2008), as it implicitly considers that the totality of the Brazilian territory is under the influence of cities. In addition, in spite of political-administrative boundaries, the research recognizes that cities located in large areas of continuous occupation should not be considered as separate entities, by grouping them in larger spatial units (ACPs). Finally, REGIC's classification considers the areas of influence of the cities not only in terms of spatially continuous hinterlands but also in terms of the functional roles cities play in the national urban network, regardless of physical proximity.

\section{Conclusion}

In this paper, the functional hierarchy of the research REGIC 2007 (IBGE, 2008) was used to create origin-destination migration matrixes regarding urban levels with the purpose of addressing the processes of population concentration and dispersion in the national urban system. The growing importance of "Regional Capitals" at national level suggests a process of restructuration of the urban system, although the pace of these changes is clearly slowing down. This category regards intermediate cities and state capitals located outside the "core region" of the national settlement system, that is, the states of São Paulo and

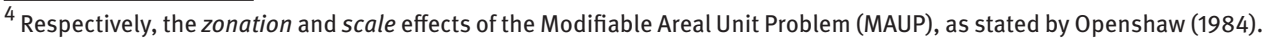


Rio de Janeiro. The same method was applied for internal migrations occurred within the boundaries of these two states, which showed very distinct patterns of deconcentration, that is, movements downwards the urban hierarchy. Therefore, despite the process of population concentration in cities of larger sizes, the inflexion of historical metropolization tendencies suggests a relative deconcentration of the urban system.

\section{References}

AMORIM FILHO; O. B.; SERRA, R. V. Evolução e perspectivas do papel das cidades médias no planejamento urbano e regional. In: ANDRADE, T. A.; SERRA ,R. V. (org.). Cidades médias brasileiras. Rio de Janeiro: Ipea, 2001.

BAENINGER, R. Migrações internas no Brasil século 21: evidências empíricas e desafios conceituais. In: CUNHA, J. M. P. da. Mobilidade espacial da população: desafios teóricos e metodológicos para o seu estudo. Campinas: Núcleo de Estudos de População (Nepo/Unicamp), 2011.

BELL, M.; WILSON, T.; CHARLES-EDWARDS, E.; UEFFING, P. The long-run decline in Australian internal migration intensities. In: CHAMPION, A.; COOKE, T.; SHUTTLEWORTH, I. (ed.). Internal migration in the developed world: are we becoming less mobile? Abingdon; New York: Routledge, 2018.

BERRY, B. J. L. Urbanization and counterurbanization. Beverly Hills: Sage Publications, 1976.

BRAGA, F. G. Conexões territoriais e redes migratórias: uma análise dos novos padrões da migração interna e internacional no Brasil. 2011. 129 f. Tese (Doutorado em Demografia) - Centro de Desenvolvimento e Planejamento Regional, Faculdade de Ciências Econômicas, Universidade Federal de Minas Gerais (Cedeplar/Face/UFMG), Belo Horizonte, 2011.

BRAGA, F. G.; FAZITO, D. Análise de redes sociais e as conexões territoriais da migração no Brasil: padrões estruturais da migração interna entre 1980 e 2000. In: ENCONTRO NACIONAL DE ESTUDOS POPULACIONAIS, 17., 2010, Caxambu. Anais [...]. Caxambu: Abep, 2010.

BRITO, F. O deslocamento da população brasileira para as metrópoles. Estudos Avançados, v. 20, n. 57, p. 221-236, 2006.

BRITO, F. As migrações internas no Brasil: um ensaio sobre os desafios teóricos recentes. Belo Horizonte: UFMG/Cedeplar, 2009. (Texto para discussão, 366).

CAMARANO, A. A.; BELTRÃO, K. I. Distribuição espacial da população brasileira: mudanças na segunda metade deste século. Rio de Janeiro: Ipea, 2000. (Texto para discussão, 766).

CANO, W. Novas determinações sobre as questões regionais e urbanas após 1980. Revista Brasileira de Estudos Urbanos e Regionais, v. 13, n. 2, p. 27-53, nov. 2011.

CARVALHO, R. C. Exploring the changing patterns of population (re)distribution in Brazil: a multiscale and multidimensional approach. 2017.123 f. Tese (Doutorado em Demografia) - Centro de Desenvolvimento e Planejamento Regional, Faculdade de Ciências Econômicas, Universidade Federal de Minas Gerais (Cedeplar/Face/UFMG), Belo Horizonte, 2017.

CHÁVEZ GALINDO, A. M.; VIGNOLI, J. R.; ACUÑA, M.; BARQUERO, J.; MACADAR, D.; CUNHA, J. M. P. da; SOBRINO, J. Migración interna y cambios metropolitanos: ¿qué está pasando en las grandes ciudades de América Latina? Revista Latinoamericana de Población, ano 10, n. 18, p. 7-41, 2016.

CORRÊA, R. L. Construindo o conceito de cidade média. In: SPOSITO, M. E. B. (org.). Cidades médias: espaços em transição. 1. ed. São Paulo: Expressão Popular, 2007. 
CUNHA, A. S. O Índice de Eficácia Migratória: suas raízes e o seu uso na análise e interpretação dos movimentos migratórios. 2014. Available at: 〈http://www.academia.edu/〉. Access on: 05 Feb. 2016.

DINIZ, C. C. Desenvolvimento poligonal no Brasil: nem desconcentração, nem contínua polarização. Nova Economia, Belo Horizonte, v. 31, n. 1, p. 35-64, set. 1993.

FIELDING, A. Counterurbanization in Western Europe. Progress in Planning, v. 17.1, p. 1-52, 1982.

HALL, P. Decentralitation wthout end? A re-valuation. In the expanding city. London: Academic Press, 1983.

IBGE - Instituto Brasileiro de Geografia e Estatística. Metodologia do censo demográfico 2010. Rio de Janeiro: IBGE, 2013. (Relatórios metodológicos, ISSN 0101-2843; v.41).

IBGE - Instituto Brasileiro de Geografia e Estatística. Regiões de Influência das Cidades 2007 (Areas of Influence of Cities 2007). Rio de Janeiro: IBGE, 2008.

IPEA - Instituto de Pesquisa Econômica Aplicada. Série Caracterização e Tendências da Rede Urbana do Brasil. Brasília: Ipea, IBGE, Unicamp, 2002.

JANOSCHKA, M. El nuevo modelo de la ciudad latinoamericana: fragmentación y privatización. Revista Eure, Santiago de Chile, v. 28, n. 85, p. 11-20, 2002.

LENCIONI. S. Metropolização do espaço: processos e dinâmicas. In: FERREIRA, A.; RUA, J.; MARAFON, G. J.; SILVA, A. C. P. (org.). Metropolização do espaço: gestão territorial e relações urbano-rurais. 1. ed. Rio de Janeiro: Consequência, 2013. p. 17-34.

MARTINE, G. A redistribuição espacial da população brasileira durante a década de 80 . Brasília, Ipea, 1994 (Textos para Discussão, 329).

MARTINE, G.; DINIZ, C. C. Economic and demographic concentration in Brazil: recent inversion of historical patterns. In: JONES, G. W.; VISARIA, P. (ed.). Urbanization in large developing countries: China, Indonesia, Brazil and India. Oxford: Oxford University Press, 1997.

MARTINE, G.; CAMARGO, L. Crescimento e distribuição da população brasileira: tendências recentes. Revista Brasileira de Estudos de População, Campinas, v. 1, n. 2, p. 99-143, jan./dez. 1984.

MATOS, R.; BAENINGER, R. Migração e urbanização no Brasil: processos de concentração e desconcentração espacial e o debate recente. Cadernos do Leste, Belo Horizonte, v. 6, n. 6 , p. 7-44, 2004.

MATTOS, C. A. Globalización y metamorfosis metropolitana en América Latina: de la ciudad a lo urbano generalizado. Revista de Geografía Norte Grande, n. 47, p. 81-104, 2010.

MONTE-MÓR, R. L. M. Urbanização extensiva e lógicas de povoamento: um olhar ambiental. In: SANTOS, M. et al. (org.). Território, globalização e fragmentação. São Paulo: Hucitec/Anpur, 1994. p. 169-181.

MONTE-MÓR, R. L. M. Cidade e campo, urbano e rural: o substantivo e o adjetivo. In: FELDMAN, S.; FERNANDES, A. (ed.). 0 urbano e o regional no Brasil contemporâneo: mutações, tensões, desafios. Salvador, Bahia: EDUFBA, 2007. p. 93-114.

OPENSHAW, S. The modifiable areal unit problem. Norwich: GeoBooks, 1984. (Concepts and Techniques in Modern Geography, 38).

QUEIROGA, E. F.; BENFATTI, D. M. Entre o nó e a rede, dialéticas espaciais contemporâneas: 0 caso da Metrópole de Campinas diante da Megalópole do Sudeste do Brasil. Revista Brasileira de Estudos Urbanos e Regionais, v. 9, n. 1, p. 41-52, 2007. 
REES P.; BELL, M.; KUPISZEWSKI, M.; KUPISZEWSKA, D.; UEFFING, P.; BERNARD, A.; CHARLES-EDWARDS, E.; STILLWELL, J. The impact of internal migration on population redistribution: an international comparison. Population, Space and Place, v. 23, n. 6, 2016.

RIGOTTI, J. I. R.; CUNHA, J. M. P. da. A migração interna nos últimos 50 anos: (des)continuidades, rupturas e recrudescimentos. In: REUNIÓN NACIONAL DE INVESTIGACIÓN DEMOGRÁFICA EM MÉXICO, 11., 2012. Anais [...]. Águas Calientes: Sociedad Mexicana de Demográfia (SOMEDE), 2012.

RIGOTTI, J. I. R. A geografia dos fluxos populacionais brasileiros. Estudos Avançados, São Paulo, V. 20, n. 57, p. 237-254, maio/ago. 2006.

RODRÍGUEZ, J.; ROWE, F. How is internal migration reshaping metropolitan populations in Latin America? A new method and new evidence. Population Studies, v. 72, n. 2, p. 253-273, 2018.

SILVA, K. A.; CUNHA, J. M. P. da; ORTEGA, G. M. Um olhar demográfico sobre a constituição da macrometrópole paulista: fluxos populacionais, integração e complementaridade. Cadernos Metrópole, São Paulo, v. 19, n. 40, p. 721-748, 2017.

\section{About the authors}

Rodrigo Coelho de Carvalho is a geographer and $\mathrm{PhD}$ in demography.

Elin Charles-Edwards is a population geographer and demographer. Senior Lecturer in Human Geography at the School of Earth and Environmental Sciences, Faculty of Science, The University of Queensland (Australia).

\section{Contact address}

\section{Rodrigo Coelho de Carvalho}

Rua Engenheiro Caetano Lopes, 312, apto. 801, Bairro Comiteco

30315-450 - Belo Horizonte-MG, Brazil

\section{Elin Charles-Edwards}

The University of Queensland, Chamberlain Building (35), Room 534, St. Lucia

QLD 4072 - Brisbane-QLD, Australia

\section{Resumo}

Os fluxos migratórios entre os níveis da hierarquia urbana brasileira no período 1980-2010

Na década de 1980, observou-se uma inflexão na redistribuição espacial da população brasileira, atribuída à relativa descentralização econômica iniciada na década de 1970, especialmente das atividades industriais. Essas mudanças no espaço econômico nacional levaram a alterações drásticas nos volumes e direções dos fluxos migratórios. Este artigo investiga o impacto da mudança dos padrões migratórios na hierarquia urbana brasileira, ao longo das últimas três décadas, para determinar se um processo de desconcentração, apontado por alguns autores, está de fato em andamento. Os fluxos migratórios entre os diferentes níveis da hierarquia urbana foram calculados por meio de dados censitários e representados visualmente em uma série de gráficos. Se um processo de desconcentração está ocorrendo, um aumento dos fluxos dos centros urbanos posicionados nos níveis hierárquicos superiores para os centros de menor ordem 
seria esperado. Este estudo indica um processo de concentração populacional em cidades de tamanhos maiores, mas não no nível mais alto da hierarquia urbana - o que sugere a inflexão das tendências históricas de metropolização no Brasil. A crescente importância das "Capitais Regionais”, o segundo nível mais alto, sugere um processo de reestruturação e descompressão relativa do sistema urbano, embora o ritmo dessas mudanças esteja desacelerando.

Palavras-chave: (Re)distribuição espacial da população. Desconcentração. Migrações internas.

\section{Resumen}

Los flujos migratorios entre niveles de la jerarquía urbana brasileña en el período 1980-2010

En la década del ochenta se observó una inflexión en la redistribución espacial de la población brasileña, atribuida a la relativa descentralización económica, iniciada en la década del setenta, especialmente de las actividades industriales. Estos cambios en el espacio económico nacional llevaron a cambios drásticos en los volúmenes y las direcciones de los flujos migratorios.

Este artículo investiga el impacto del cambio de los patrones migratorios en la jerarquía urbana brasileña a lo largo de las últimas tres décadas para determinar si un proceso de desconcentración, señalado por algunos autores, está de hecho en marcha. Los flujos migratorios entre los diferentes niveles de la jerarquía urbana se calcularon con datos censales y representados visualmente en una serie de gráficos. Si se está produciendo un proceso de desconcentración, un aumento de los flujos desde los centros urbanos posicionados en los niveles jerárquicos más altos hacia los centros de orden inferior sería esperado. Este estudio indica un proceso de concentración de la población en las ciudades más grandes, pero no en el nivel más alto de la jerarquía urbana, lo que sugiere la inflexión de las tendencias históricas de metropolización en Brasil. La creciente importancia de las capitales regionales, el segundo nivel más alto, sugiere un proceso de reestructuración y descompresión relativa del sistema urbano, aunque el ritmo de estos cambios esté desacelerando.

Palabras clave: (Re)distribución espacial de la población. Desconcentración. Migraciones internas.

Received for publication in 10/04/2019

Approved for publication in 14/10/2019 